\title{
WORKING
}

\section{Relationship lending and SMEs' funding costs over the cycle: why diversification of borrowing matters}

\section{Mikael Béatriz ${ }^{1}$, Jérôme Coffinet $^{2} \&$ Théo Nicolas $^{3}$}

\author{
December 2018 \\ WP \# 705
}

\begin{abstract}
Using a unique panel design that enables to control for bank, firm, market and loan heterogeneities, we confirm that relationship lenders charge higher rates in good times and lower rates in bad times. However, we show that risky single-bank firms do not benefit from this insurance mechanism and are "held-up" by relationship lenders. Local bank competition and higher non-bank finance dependence alleviate this informationmonopolistic behavior. Finally, long-term loans and small, non-trading-oriented and wellcapitalized banks drive the benefits of relationship lending.
\end{abstract}

Keywords: relationship lending, financial crisis, interest rates, bank lending channel, SME, competition.

JEL classification: D82, E32, E51, G01, G21.

1 At the time of writing the article, Mikael Beatriz was seconded to Statistics directorate, Mikael.beatriz@gmail.com

${ }^{2}$ Statistics directorate, Jerome.coffinet@,banque-france.fr

${ }^{3}$ Statistics directorate and Paris school of economics, theo.nicolas@,banque-france.fr

We thank Jose Berrospide, Jezabel Couppey-Soubeyran, Olena Havrylchyk, Christian Pfister and Patrick Sevestre for their relevant comments. The authors are also grateful to participants at the IFABS 2017 conference and seminar participants at the Banque de France for helpful comments. All remaining errors are ours.

Working Papers reflect the opinions of the authors and do not necessarily express the views of the Banque de France. This document is available on publications.banque-france.fr/en 


\section{NON-TECHNICAL SUMMARY}

Among the ways that enable firms to overcome credit restrictions, relationship lending turns out to be one of the most salient. Through proprietary information and multiple interactions, closer and longer-lasting relationships not only mitigate small and mediumsized enterprises' (SMEs) credit risk but also ensure the continuation of lending during crises. Yet, the effect of relationship lending on interest rates has always been unclear due to competition issues between external sources of finance. Indeed, the soft information acquired by relationship lenders during good times may give them an informational advantage that increases in relative terms during a financial crisis, when firms have no alternative funding options. Do relationship lending benefits depend on firms' ability to diversify their borrowing? Does multiple banking or local bank competition shield firms from opportunistic relationship lenders? If so, how do bank and firm heterogeneities influence interest rate setting?

To address these questions, we draw on measures of single banking and credit concentration and show that the beneficial effect of relationship lending on SME's funding costs depends on their ability to diversify their borrowing. Given that single-bank firms account for a substantial share of the firm population (for example, about $60 \%$ of firms in the French Credit Register), focusing on their access to credit during the crisis is essential to our understanding of the economic recovery following the Great Recession.

In order to identify the effects of relationship lending on interest rates, we draw on five different databases encompassing 11,278 French SMEs over the period Q1 2006-Q4 2015. We first capture the protean nature of relationship lending both in terms of its length and its scope (i.e. the importance of the lending bank within the firm's outstanding amount of credit) and focus on the geographical distance between a lender and its borrower in our robustness analysis. All of these measures serve as proxies for the ability of lenders to accumulate information on borrowers.

As regards diversification of borrowing, we use two different measures. First, the single versus multiple banking indicator measures firms' ability to diversify their borrowing within their existing pool of lenders. Second, a Herfindahl Hirschman Index (HHI) on banks' deposits at the level of each French département captures firms' ability to diversify their lending within their local credit market.

To our knowledge, our paper is the first to provide evidence that the countercyclical effect of relationship lending depends on the SME's ability to diversify its borrowing within its pool of lenders. We find that the benefits of relationship lending vanish for SMEs with limited funding options. While relationship lenders "hold up" risky single-bank firms regardless of their position in the cycle, measures of diversification are associated with higher relationship lending benefits during crises. Interestingly, long-term credit and small, well-capitalized and non-trading-oriented banks drive the benefits of relationship lending. Finally, we find that large, trading-oriented and well- banks drive the opportunistic behaviour highlighted previously. 


\title{
The countercyclical effect of relationship lending according to diversification of borrowing
}

\begin{tabular}{|c|c|c|c|}
\hline $\begin{array}{l}\text { Diversification of } \\
\text { borrowing }\end{array}$ & Measures & Good times & Bad times \\
\hline \multirow[t]{2}{*}{ Low } & Single banking & $\begin{array}{l}\text { Higher monitoring } \\
\text { costs }\end{array}$ & $\begin{array}{c}\text { Opportunistic lending } \\
\text { behaviour }\end{array}$ \\
\hline & Low banking competition & Higher funding costs & Higher funding costs \\
\hline \multirow[t]{2}{*}{ High } & Multiple banking & $\begin{array}{l}\text { Higher monitoring } \\
\text { costs }\end{array}$ & Continuation lending \\
\hline & High banking competition & Higher funding costs & Lower funding costs \\
\hline
\end{tabular}

Note: the figure presents our main results concerning the countercyclical effects of relationship lending on SMEs funding costs according to different measures of diversification of borrowing.

\section{Relation bancaire et coût de financement des PME au cours du cycle : pourquoi la diversification des emprunts est importante}

\begin{abstract}
RÉSUMÉ
En s'appuyant sur une base de données granulaire qui permet de prendre en compte l'hétérogénéité des banques, des entreprises, des prêts et des marchés du crédit locaux, nous montrons que les prêteurs relationnels pratiquent des taux plus élevés en période de croissance et des taux plus bas en période de crise. Cependant, nous constatons que ce mécanisme assurantiel dépend de la capacité des PME à diversifier leurs emprunts auprès de plusieurs banques. Les PME monobancaires risquées qui empruntent auprès d'une banque relationnelle sont ainsi systématiquement associées à des taux plus élevés. La concurrence bancaire locale et l'accès aux financements de marché atténuent cet effet d'opportunisme monopolistique. Enfin, les bénéfices de la relation bancaire sont concentrés sur les prêts à long terme et les petites banques bien capitalisées non orientées vers le trading.
\end{abstract}

Mots-clés : relation bancaire, crise financière, taux d'intérêt, canal du crédit, PME, concurrence bancaire.

Les Documents de travail reflètent les idées personnelles de leurs auteurs et n'expriment pas nécessairement la position de la Banque de France. Ils sont disponibles sur publications.banque-france.fr 


\section{Introduction}

Among the ways that enable firms to overcome credit restrictions, relationship lending turns out to be one of the most salient. Through proprietary information and multiple interactions, closer and longer-lasting relationships not only mitigate the asymmetric information costs of lending to small and medium-sized enterprises (SMEs) but also create an intertemporal smoothing of contract terms that ensures the continuation of lending during crises (Boot, 2000). Yet, the effect of relationship lending on interest rates has always been unclear due to competition issues between external sources of finance (Sharpe, 1990, Rajan, 1992). Do relationship lending benefits depend on firms' ability to diversify their borrowing? Does multiple banking or local bank competition shield firms from opportunistic relationship lenders? If so, how do bank and firm heterogeneities influence interest rate setting?

To address these questions, we use a unique panel design that enables us to control for bank, firm, market and loan characteristics. Unlike the influential literature on credit supply shocks (Khwaja and Mian, 2008), we include single-bank firms in the analysis and show that the beneficial effect of relationship lending on SME's funding costs depends on their ability to diversify their borrowing. Given that single-bank firms account for a substantial share of the firm population (for example, about $60 \%$ of firms in the French Credit Register), focusing on their access to credit during the crisis is essential to our understanding of the economic recovery following the Great Recession.

In the past 30 years, a vast amount of literature has investigated, both theoretically and empirically, the role of relationship lending for firm financing..$^{2}$ Attention has only recently turned to the specific role of relationship lending over the cycle. The main as-

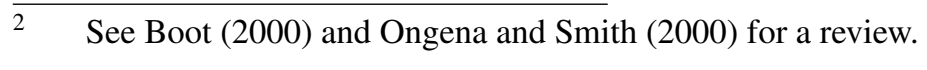


sumption is that a relationship bank could stipulate an implicit lending contract that includes insurance against fluctuations in lending rates, thus playing a significant role as shock absorber (Berger and Udell, 1992; Berlin and Mester, 1999). More recently, Bolton et al. (2016) have modeled relationship lending over the cycle and shown empirically that relationship banks charge higher rates in normal times, but offer continuation lending at more favourable terms than transaction banks to profitable firms in a crisis. Nonetheless, due to the lack of micro data, only few papers have tested the insulating effect of relationship lending on interest rates during crises (Gambacorta and Mistrulli, 2014; Sette and Gobbi, 2015). Above all, their empirical methodology focuses exclusively on Italian multiple-bank firms.

In contrast to these results, relationship lenders may also provide less support than transactional lenders during a financial crisis. Following the "hold-up" hypothesis (Rajan, 1992), some recent studies underline the crucial role of market and micro conditions and show that substitution with other financing sources matters. Thus, the soft information acquired by relationship lenders during good times gives them an informational advantage that increases in relative terms during a financial crisis, when firms are less likely to diversify their borrowing. Despite the rise in loan spreads in bad times, firms with access to public debt markets pay lower spreads, and spreads increase significantly less during recessions (Santos and Winton, 2008). Given the bank-dependent nature of SMEs (Gertler and Gilchrist, 1994), multiple banking or local bank competition should be considered as an alternative or a complement to this "hold-up" behaviour.

In order to identify the effects of relationship lending on interest rates, we draw on five different databases encompassing 11,278 French SMEs over the period Q1 2006-Q4 2015. We first capture the protean nature of relationship lending both in terms of its length and its scope (i.e. the importance of the lending bank within the firm's outstanding amount of credit) and focus on the geographical distance between a lender and its borrower in our 
robustness analysis. All of these measures serve as proxies for the ability of lenders to accumulate information on borrowers and account for an intertemporal implicit contract between borrowers and lenders.

As regards diversification of borrowing, we use two different measures. First, the single versus multiple banking indicator measures firms' ability to diversify their borrowing within their existing pool of lenders. Second, a Herfindahl Hirschman Index (HHI) on banks' deposits at the level of each French département captures firms' ability to diversify their lending within their local credit market.

To our knowledge, our paper is the first to provide evidence that the countercyclical effect of relationship lending depends on the SME's ability to diversify its borrowing within its pool of lenders. We find that the benefits of relationship lending vanish for SMEs with limited funding options. While relationship lenders "hold up" risky singlebank firms regardless of their position in the cycle, measures of diversification are associated with higher relationship lending benefits during crises. Interestingly, long-term credit and small, well-capitalized and non-trading-oriented banks drive the benefits of relationship lending. Finally, we find that large, trading-oriented and well- banks drive the opportunistic behaviour highlighted previously.

This paper contributes to a large literature that investigates the role of multiple banking relationships. Although Diamond (1984)'s classical delegated monitoring theory argues that exclusive lending relationships minimise loan rates by avoiding duplication of monitoring costs, a few papers suggest that firms can reduce interest rates by borrowing from several banks. For example, Sharpe (1990) and Rajan (1992) stress that in an exclusive bank relationship the informationally privileged bank might use its bargaining power over risky firms to extract rents from loan contracts. Some studies thus provide evidence of the existence of "hold-up" costs in bank-firm relationships (Farinha and Santos, 2002; Ioannidou and Ongena, 2010). Following the "hold-up" hypothesis, our results suggest that the 
absence of diversification during crises enables relationship lenders to make use of their informational monopoly.

Our paper also adds to the growing empirical evidence that relationship lending shielded firms from tighter credit conditions during the Great Recession. Most of these papers use loan or loan-application data from European countries credit registers to identify the impact of bank-firm relationships on access to credit. Overall, firms with a stronger credit history, measured by the firm-bank credit volume before the crisis (Iyer et al., 2014) or the existence of a checking account (Puri et al., 2011), were partially shielded from the credit crunch. Similarly, firms with longer lending relationships (Sette and Gobbi, 2015) or located closer to their bank's headquarters (Bolton et al., 2016) had easier access to credit, at a lower cost.

Finally, our findings are also relevant for the credit channel literature that examines how shocks to the banks balance sheets dampen credit supply to firms (Bernanke and Gertler, 1989; Holmstrom and Tirole, 1997; Adrian and Shin, 2010). Extensive evidence supports the view that banks pass on monetary policy tightening (Kashyap and Stein, 2000; Jiménez and Ongena, 2012) and unexpected liquidity shocks (Peek and Rosengren, 2000; Khwaja and Mian, 2008) to their borrowers. These studies emphasise the major role played by bank capital or bank liquidity in helping banks to weather the storm. However, much less is known about how bank heterogeneities and bank business models affect credit supply according to relationship lending. Hence, a further contribution of the paper is to identify the bank characteristics that strengthen the insulating effect of relationship lending during bad times.

The remainder of the paper is structured as follows. The next section presents the theoretical basis for our research hypotheses. Section 3 outlines our empirical strategy. Section 4 presents our data sources and characterises our sample. Section 5 discusses our results. Section 6 checks the robustness of the results. Section 7 concludes. 


\section{Theoretical predictions}

The recent literature sheds some light on continuation lending provided by relationship lenders during downturns. However, the effect of diversification of borrowing on this hedging mechanism remains unclear. In this section, we present theoretical predictions and explore several research hypotheses that we then test empirically.

\subsection{Hypothesis 1}

When exit options are perfect, competition reduces relationship-specific investments. According to the contract theory, competitive local credit markets or multiple banking should lower banks' willingness to invest in relationship lending because effective or potential competition reduces their marginal rents of closer relationships (see Harris and Holmstrom (1982)). Yet, the theoretical literature has, since then, brought up mixed predictions on this issue since then. Indeed, according to the degree of complementarity between credit market tightness and effective diversification, the effect of relationship lending on interest rates may vary significantly. While Petersen and Rajan (1995) show that intermediaries further support borrowers if they are less likely to switch to another lender, Boot and Thakor (2000) argue that banks are more willing to engage in relationships that ensure continuation lending in order to insulate their rents from interbank competition. We argue that both single- and multiple-bank firms may benefit from relationship lending as long as it is profitable for relationship lenders.$^{3}$

3 One should also note that for a given multiple-bank firm, exit options are never perfect so that, among its pool of lenders, switching from its main bank to another competitive lender may be costly. In this regard, Carletti et al. (2007) studied bank's incentive to engage in relationship lending together with other banks. 
Under relationship banking, a bank incurs a monitoring cost to assess a firm's credit risk. As in Bolton et al. (2016), we assume that in normal times relationship banks charge higher rates to make up both for higher screening costs and capital buffers. In return, relationship lenders may support borrowers to a greater extent than transactional lenders during a financial crisis (Sette and Gobbi, 2015).

However, this hedging mechanism may depend on the relationship bank's bargaining power. Indeed, in the theoretical model put forward by Rajan (1992), the relationship bank knows whether a firm asking for a new loan is going to default, whereas the transaction bank only knows the firm's probability of success. Given this asymmetric information, competition between relationship and transaction banks is negatively correlated to firms' level of risk. For risky firms, relationship banks face weaker competition and increase their rents. Since firms' probability of default increases during downturns, relationship lenders may exploit their monopolistic advantage to charge higher rates. Consequently, our first hypothesis can be broken down into two parts:

(H1a): relationship banks charge higher rates in good times and lower rates in bad times for multiple-bank firms.

(H1b): relationship banks charge higher rates in good times and lower rates in bad times only for low-risk single-bank firms.

\subsection{Hypothesis 2}

Given the importance of diversification within a pool of banks that are already lending to a firm, one should also investigate whether local bank competition affects relationship lending in the same way. In this regard, some empirical studies highlighted the non-monotonic effect of market concentration on relationship lending (Degryse and Ongena, 2007). As pointed out by Presbitero and Zazzaro (2011), this U-shaped relationship is due to the interplay between market concentration and banks' organisational structure: 
bank competitors should react to competitive pressure by focusing their efforts on their comparative lending advantage (i.e. their preferred lending technology). Non hierarchical small banks should therefore focus even more closely on relationship lending when interbank competition is high. Assuming that local competition may act as effective diversification of borrowing for firms and may reinforce relationship lending specialization for small banks, a second research hypothesis can be divided into two parts:

(H2a): the insurance mechanism depends on local interbank competition and benefits firms involved in competitive credit markets.

(H2b): higher interbank competition increases relationship lending benefits for small banks.

\subsection{Hypothesis 3}

In the Bolton et al. (2016) model, relationship banks suffer higher intermediation costs because they hold a larger buffer of capital against expectations of higher rollover lending. At the same time, under relationship banking, banks incur a monitoring cost that enables them to evaluate firm riskiness perfectly. Unlike these authors, we presume that relationship banks make use of their higher amounts of capital to gain market power. As

interest rates are positively correlated with monitoring costs, higher "monitoring capital" may affect banks' ability to charge lower rates, thus attracting borrowers during normal times. Accordingly, our third research hypothesis is as follows: well-capitalized relationship banks charge a lower premium in good times and a lower rate in bad times $(\mathrm{H} 3)$.

\subsection{Hypothesis 4}

The capacity to deliver relationship lending differs across banks. For instance, continuation lending during crises depends on the banks' willingness to focus its lending technologies on soft information gathered by the loan officer through direct contact with 
the borrower. In this view, larger and more organisationally complex banks tend to be more transaction-driven (Berger and Udell, 2002; Liberti and Mian, 2009). This argument also stems from organisational models that emphasize managerial diseconomies coming from multiple activities in large and complex organisations (Williamson, 1967). For these reasons, a last research hypothesis can be tested: the countercyclical effect of relationship lending on interest rates is higher for small and retail-oriented banks (H4).

\section{Empirical strategy}

\subsection{Bank-firm relationship and diversification measures}

\subsubsection{Relationship lending measures}

Relationship lending is defined in contrast to transactional lending. On the one hand, transaction-oriented banks are associated with non-recurrent transactions with customers and rely on hard information to assess borrowers' creditworthiness (Boot and Thakor. 2000). On the other hand, according to the definition provided by Boot (2000), relationship lending may be defined as the "provision of financial services by a financial intermediary" that $(i)$ invests in obtaining customer-non-public-specific information (ii) assesses the profitability of this information through multiple interactions with the same client over time and across products. In this regard, relationship lenders rely primarily on soft information on borrowers' qualitative characteristics and subjective information on the borrowers. To capture the different channels through which relationship lending affects interest rate setting, two proxies for the ability of lenders to accumulate information are described hereafter.

Measure 1: length of the relationship. The longer the relationship, the more precise the lenders' knowledge of borrowers' credit risk. Throughout our analysis, the duration corresponds to the elapsed time between the first relationship established between a firm and 
a bank and the last one. However, a technical difficulty arises when dealing with this measure since the data source does not include the full history of every relationship (Ongena and Smith, 2001). Indeed, we are faced with a left censure given that our credit register starts in 2003. The distribution of relationship lengths is therefore likely to change over time because the length is incremented every year. To correct this measure, we build a relative indicator of the length by dividing the absolute relationship duration of firm $i$ with bank $b$ at time $t$ by the time elapsed since 2003. This enables us to consistently compare firms over the cycle.

Measure 2: scope of the relationship. The scope of the relationship is a dummy which takes the value of 1 when the firm contracts a loan from its main bank and 0 otherwise. Banks holding a larger share of credit are likely to have better access to information about borrowers (Elsas, 2005; Sette and Gobbi, 2015; Bolton et al., 2016). Relationship lenders

that are disproportionately exposed to their borrowers may have incentives to keep lending in order to avoid weakening their capital base (Boot, 2000).

Although these measures account for intertemporal implicit contracts, they may also capture the "hold-up" power based on the costs for borrowers of switching to different lenders (Sharpe, 1990; Rajan, 1992).

\subsubsection{Measures of borrowing diversification}

Measure 1: single versus multiple banking. Our first measure corresponds to the structure of information available to lenders (i.e. private versus shared information). Like the scope of the relationship, single-banking has sometimes been used as a relationship lending measure in the seminal literature (Petersen and Rajan, 1994). However, we assume that single banking considerably weakens the firm's bargaining power with respect to its unique bank given that diversification of borrowing is more difficult in the presence of switching costs. In the modern theory of financial intermediation (Diamond, 1984), exclusive lending rela- 
tionships minimise loan rates by preventing a duplication of monitoring costs. At the same time, multiple banking is also perceived as a solution to the "hold-up" problem (Farinha and Santos, 2002; Ioannidou and Ongena, 2010) and can mitigate the volatility of credit supply stemming from a liquidity risk on the bank side (Detragiache et al., 2000). In our analysis, a firm is considered to be a single-bank firm if it has had a relationship with only one bank since the starting date of the French Credit Register. Consequently, the singlebank dummy takes the value of 0 if a firm has had two different relationships in the past, and remains the same even if the firm temporarily borrows from only one bank thereafter ${ }^{4}$

Measure 2: Herfindahl Hirschman Index. Our second measure of diversification is based on the Herfindahl-Hirschman Index of banks deposits at the level of each French département. We define a Competition dummy that equals 1 when the Herfindahl-Hirschman Index belongs to the first quartile of the distribution and 0 otherwise. In doing so, we capture local diversification issues since firms are more likely to diversify their borrowing in less concentrated credit markets (Gobbi and Sette, 2013). Besides, at the bank level, the concentration of local credit markets could also affect the banks' propensity to use relationship lending technologies (Petersen and Rajan, 1995; Boot and Thakor, 2000; Elsas, 2005).

\subsection{Cycle measures}

As regards the decomposition of the business cycle, we first rely on a set of real and financial indicators, such as the output gap released by the OECD, and the ECB refinancing rate. More specifically, we identify two main periods in our sample using the Q1 2009 break (figure 1). In our analysis, our crisis period corresponds to a negative output gap and

$4 \quad$ While most of studies on multiple banking only focus on bank-firm relationships at a specific point in time in the credit register, our measure is backward-looking and hinges on the whole credit history. 
to a lower level of Gross Fixed Capital Formation as compared to the pre-crisis period (figure 3). Thus, it seems appropriate to consider that France was still in the doldrums before Q4 2015. Furthermore, Q1 2009 also marks the beginning of a very accommodative monetary policy stance adopted by the ECB. To account for this change of regime, we therefore use the Q1 2009 break in the main regressions and study more detailed decompositions in our robustness analysis.

\subsection{Identification strategy}

Identifying the causal effect of relationship lending and diversification of borrowing on interest rate setting entails three main challenges. First, borrowers' observable and unobservable characteristics may be correlated with measures of relationship lending or multiple lending. This mechanism is particularly at play in bad times: safer borrowers may obtain more credit during a financial crisis, which results in a spurious positive correlation.

Second, the asymmetric impact of the financial crisis on banks is likely to be correlated with the granting of loans as well as with the characteristics of lending relationships. Engaging in a relationship with a well-capitalized or liquid bank at the onset of the crisis may thus mitigate the interest rate rise stemming from the interbank market freeze.

Third, multiple lending is also affected by entry costs and market conditions. Under the assumption that the number of banks reflects the overall level of bank competition, a large number of banks in the economy raises the probability of finding a bank to contract with. Hence, according to the degree of complementarity between credit market tightness and effective diversification, the effect of multiple banking on interest rate may vary dramatically.

Finally, another concern relates to the unexpected nature of the Great Recession. The firm relationship structure at the onset of the crisis is supposed to be exogenous with respect to the crisis implying firms did not adjust the structure (number of banks, share, 
duration) of their relationships in anticipation of the shock. This is likely to be the case in France, as the financial crisis originated in the US financial sector and the default of Lehman was largely unanticipated (Schularick and Taylor, 2012).

To address these identification challenges, we use fixed effects regressions and include firm, bank, loan and market variables to account for both time-invariant and time-varying characteristics 5

\subsection{The model}

The specification that we estimate is at the new loan level:

$$
\begin{gathered}
i_{j b t}=\beta_{1} F_{j t-1}+\beta_{2} B_{b t-1}+\beta_{3} L_{j b t}+\beta_{4} M_{j t}+\beta_{5} R_{j b t}+\beta_{6} \text { Crisis }_{t} \\
+\beta_{7} R_{j b t} \times \text { Crisis }_{t}+\alpha_{j}+\gamma_{b}+\lambda_{t}+\epsilon_{j b t}
\end{gathered}
$$

Where $i_{j b t}$ is the new loan interest rate granted by bank $b$ to firm $j$ at time $t$. $F, B, L$ and $M$ are respectively matrices of firm, bank, loan and market controls. $R$ is our measure of relationship lending and the Crisis dummy equals 0 from Q1 2006 to Q4 2008 and 1 from Q1 2009 to Q4 2015. $\alpha_{j}, \gamma_{b}$, and $\lambda_{t}$ are respectively firm, bank, and time fixed effects.

Changes in banks' pricing could influence some of the firm and bank characteristics and raise endogeneity issues. On the one hand, firms' current and past balance sheets are significant determinants of loan pricing. On the other, interest rates charged by banks affect firms' cash flows and financial wealth. To prevent such an endogeneity bias, we use

$5 \quad$ Note that, contrary to the use of the within-firm estimator in the seminal work of Khwaja and Mian (2008), our fixed effects methodology do not control for all observed and unobserved time-varying firm heterogeneity. 
lagged firm- and bank-level variables which eliminate reverse causality. ${ }^{6}$

As regards the differential effect of relationship lending according to diversification or other bank and firm heterogeneities, we include triple interactions and extend equation 1 as follows :

$$
\begin{gathered}
i_{j b t}=\beta_{1} F_{j t-1}+\beta_{2} B_{b t-1}+\beta_{3} L_{j b t}+\beta_{4} M_{j t}+\beta_{5} R_{j b t}+\beta_{6} \text { Crisis }_{t}+\beta_{7} H_{j b t} \\
+\beta_{8} R_{j b t} \times \text { Crisis }_{t}+\beta_{9} R_{j b t} \times H_{j b t}+\beta_{10} H_{j b t} \times \text { Crisis }_{t} \\
+\beta_{11} R_{j b t} \times \text { Crisis }_{t} \times H_{j b t}+\alpha_{j}+\gamma_{b}+\lambda_{t}+\epsilon_{j b t}
\end{gathered}
$$

Where $H_{j b t}$ corresponds to variables that may have a heterogeneous effect on interest rate setting. For instance, dealing with diversification issues, $H$ could take the value of 1 when the firm is a single-bank firm and 0 otherwise.

\section{Data and descriptive statistics}

We draw on five different databases provided by the Banque de France. Table 1 shows statistics regarding variables of interest. The final database leaves us with more than 11,278 firms representing 49,798 observations.

\subsection{Credit relationships in France}

The case of French SMEs is an excellent laboratory for several reasons. In practice, these firms have a very limited access to financial markets. Despite recent initiatives launched in the framework of the Capital Market Union (CMU) in order to steer households' savings towards SMEs ("PEA-PME"), it appears clearly that French SMEs are still highly bank-dependent. As a result, while large French firms are essentially financed

$\overline{6 \quad \text { Note that firm variables are lagged by }}$ one year whereas bank variables are lagged by one quarter. 
through public debt markets, banking debt represents between 60 and $70 \%$ of SMEs' oustanding financial debt. In that context, relationship lending plays a substantial role for SMEs and multiple bank relationships might be used to lower interest rates on new loans and mitigate the "hold-up" issue.

Yet, one should note that the scope of multiple banking in France is relatively average compared to other European countries. Based on a survey of 19 European countries, Hernández-Cánovas and Koëter-Kant (2010) find that the average number of bank-firm relationships for SMEs in France is above the figures observed in Northern European countries, but below the ones observed in Southern European countries, where credit markets turn out to be more fragmented. Consistently, Fungáčová et al. (2017) report a moderately competitive credit market in France, with a Herfindahl-Hirschmann Index of 0.064 over the period 2001-2011, compared to 0.029 in Italy, 0.050 in Spain, but 0.190 in the Netherlands and 0.280 in Finland.

\subsection{Interest rates setting}

Core data come from the loan-to-loan "M-Contran" reporting and provide the interest rates on new corporate loans. This information is collected quarterly on all new loans with attributes on types of loans, borrowing sectors and types of credit institution. Participating credit institutions are selected within a partly rotating panel so as to make up a representative sample of banks. On average over the period 2006-2015, the initial dataset reports about 100,000 new loans each quarter and accounts for 345 different banks representing $75 \%$ of the total amount of corporate credit in 2015. In particular, we focus on long-term

loans (i.e. loans with a maturity of over one year, such as investment credit, leasing and housing loans) given that long-term loans require higher monitoring costs to mitigate in- 
formational asymmetry.7 As summarised in Table 1, we deal with a large diversity of outstanding amounts, maturities and rates.

\subsection{Firm-level variables}

We first match the loan-to-loan dataset with firms' balance sheet information coming from the FIBEN company database, which gathers balance sheet data on all companies with a turnover of over EUR 750,000 since 2006. Firms whose balance sheet and interest rate variables are incomplete are excluded from the original sample. We also restrict the sample to bank-dependent SMEs for which relationship lending is a key issue $]^{8}$ Thus, very small enterprises and small and medium-sized enterprises represent respectively $33.9 \%$ and $66.1 \%$ of observations in our sample. 99

To account for observable firm heterogeneities, we rely on a traditional set of measures, such as profitability (i.e. the ratio of cash flow over the sum of fixed and working capital), liquidity (i.e. the ratio of current assets over total assets of the firm), solvency (i.e. the ratio of own funds over total assets of the firm), indebtedness (the ratio of financial debt over total assets of the firm) and variables that typically proxy for the presence of asymmetric information (i.e. the size and the age of the firm) ${ }^{10}$

\subsection{Bank-firm relationship variables}

As regards bank-firm relationship variables, the French national credit register gathers data on credit exposures of all banks operating in France to all firms whose total credit

$7 \quad$ However, short-term loans are analysed in our additional results.

8 In line with the European Commission, our definition of SMEs is based on the number of employees (less than 250), turnover (less than EUR 50 million) and total assets (less than EUR 43 million).

9 Our dataset is quite balanced across sectors (2.7\% observations from agriculture, $15 \%$ from industry, $17.5 \%$ from construction, $62.4 \%$ from market services and $2.4 \%$ from non-market services).

10 To minimise the effect of gross outliers, we winsorize variables at the first and 99th percentile. 
exposure is greater than EUR 25,000. Around 4\% of observations relate to single banking in our dataset. While this percentage seems very small compared to the overall level of single-bank firms (60\%), one has to keep in mind that the smallest SMEs are de facto excluded from our sample: the latter display lower credit demand and do not reach the FIBEN threshold turnover. Yet, as pointed out above, we still keep a significant number of very small enterprises and small and medium-sized enterprises in our final dataset. All in all, the average duration of a bank-firm relationship is 17 quarters (see Table 1) but its corresponding average normalised duration stands at around $63 \%$ of the sample's average duration at a given time. Lastly, $46 \%$ of our database observations involve a loan contracted from firms' main bank.

\subsection{Market-level variables}

To assess the role of local bank competition, we compute a quarterly HerfindahlHirschman Index using the Centralisation Financière Territoriale (CEFIT) dataset. This original dataset, which covers the 95 French départements, collects monthly information on credit loans and deposits for each individual bank at the départment level. Interestingly, CEFIT contains breakdowns by types of borrowers which enables us to collect data on corporate deposits only.

\subsection{Bank-level variables}

Finally, we match the database with the French unified reporting system for financial institutions (SURFI) to assess how the strength of a bank's balance sheet is related to corporate interest rates. The bank level database contains financial statements at the nonconsolidated level on all commercial and cooperative banks in France over the period Q1 2006-Q4 2015. Our sample ends up containing 184 banks, representing 58\% of corporate credit in Q1 2006. 
Following the bank balance sheet channel thesis, we control for the heterogeneous bank response to an unexpected adverse shock. We look at traditional indicators of bank financial strength, such as solvency (i.e. bank equity over total assets of the bank), liquidity (i.e. the sum of cash, balance with the central bank, loans and advances to credit institutions and repurchase agreements over total assets of the bank), non-performing-loans and bank size (Kashyap and Stein, 2000, Jiménez and Ongena, 2012). In addition, we add other bank-specific controls that are likely to shift credit supply: (i) the ratio of deposits over total assets of the bank to analyse the effect of stable fundings during downturns and (ii) the loan-to-asset ratio to capture the retail-oriented bank business model.

\section{Empirical Results}

\subsection{Relationship lending and multiple banking over the cycle}

To assess the countercyclical effect of relationship lending, we first estimate the baseline equation 1 . The results are reported in column (1) of Table 2, Ceteris paribus, we find that a 1 unit change in the relative relationship length raises interest rates by 0.2 basis points in good times and lowers the latter by 0.1 basis point in bad times, while singlebanking has no effect on interest rates over time. The difference between the two rates is negative and equals 0.3 basis point. In a low interest rate environment, these effects are statistically significant and economically relevant.11 In line with the predictions of Bolton et al. (2016), coefficients show that relationship lenders charge higher rates in good times

$\overline{11}$ Quantitatively, a firm with a three year relationship with a bank in Q1 2008 has a normalized relationship length of 0.6 (12 quarters over 20). An 1 quarter increase in the absolute relationship length results in a 5 unit increase in the normalised relationship length to stand at 0.65 (13 quarters over 20). It thus raises interest rate by $(65-60) \times 0.2 \approx 1$ basis point. 
and lower rates in bad times.

As regards the effect of diversification of borrowing on this edging mechanism, column (2) of Table 2 presents the estimates of equation 2 with our first measure of diversification. First, the coefficients associated with Duration and Duration $\times$ Crisis remain unchanged, which indicates that multiple-bank firms are still subject to the insurance mechanism. Conversely, while the Duration $\times$ Single-banked difference suggests that single-bank firms are also facing a premium in good times, the positive and significant coefficient associated with the triple interaction Duration $\times$ Crisis $\times$ Single-banked shows that multiple banking drives the benefits of relationship lending exhibited in column (1). These findings shed new light on the relationship lending mechanism already identified in the literature: relationship lending benefits depend on the firm's ability to diversify its borrowing within its pool of lenders. $\mathrm{H} 1 \mathrm{a}$ and $\mathrm{H} 1 \mathrm{~b}$ are verified. In addition, control variables are significant and in line with economic predictions. Concerning non-linearity issues, the specification in column (3) reveals the presence of nonlinear effects of bank capital that do not affect our results.

Table 3 provides additional insights using a complementary measure of relationship lending: the scope of the relationship (i.e. the main bank) 12 Interestingly, column (1) suggests that a firm dealing with its main bank tends to contract cheaper loans during bad times, while there is no effect on funding cost during good times. Indeed, in line with Gambacorta and Mistrulli (2014) and Bolton et al.(2016), Main bank captures "incentives to monitor" effects or "skin in the game" effects. However, the positive and significant triple interaction in column (2) points to the fact that long-lasting bank-firm relationships with a main bank might be sub-optimal as interest rates rise in bad times. According to the firm's bargaining power, we find that the "hold-up" mechanism identified for single-bank

\footnotetext{
12 As a single-bank firm always deals with its main bank we restrict the sample to multiple banking.
} 
firms might arise under multiple banking.

\subsection{Insurance mechanism, market concentration and bank organisational structure}

Previous results suggest that effective diversification offers firms significant relationship lending benefits over the cycle. However, does this result hold for potential diversification given bank concentration? To account for credit market competition at the département level, we use a dummy variable that equals 1 when the Herfindahl-Hirschman Index belongs to the first quartile of the distribution and zero otherwise. The results of the baseline estimation are shown in the first column of Table 4 In particular, the negative and significant triple interaction indicates that banking competition plays the same role as multiple banking: the higher the market concentration, the lower the relationship lending benefits in bad times. Consequently, firms in competitive markets tend to have a greater bargaining power vis-à-vis banks insofar as they are more likely to switch bank easily. Alternatively, at bank level and in line with Boot and Thakor (2000), market competition forces banks to protect their rents by engaging more in relationship lending. Overall, this result suggests that market competition could play a similar role as diversification at firmlevel in order to mitigate the "hold-up" faced by single-bank firms: H2a is corroborated.

In addition, we investigate the effects of market competition on relationship lending benefits according to bank organisational structures. We first distinguish small banks from large banks using a dummy variable that takes the value of 1 when total bank assets belong to the first quartile of the distribution and zero otherwise. We then run model 2 on these two sub-samples in columns (2) and (3), respectively. In line with Presbitero and Zazzaro (2011) and $\mathrm{H} 2 \mathrm{~b}$, we find that competition has a positive effect on relationship lending benefits (i.e. a negative and significant triple interaction) only for small banks whose organisational structures are likely to be non-hierarchical. 


\subsection{Bank and firm heterogeneity}

We next focus on firm and bank heterogeneity to better understand why relationship lending insulates firms from tighter credit conditions during crises.

We start by examining whether relationship lending provides more support to risky firms during crises. We interact relationship lending benefits across the cycle with three different dummies that account for firm riskiness: the "speculative grade" of the Banque de France rating system and two synthetic indexes based on the distribution of our firm variables that represent ease of access to external financing. ${ }^{13}$ The results are shown in columns (1), (4) and (7) of Table 5. Overall, the triple interaction Duration $\times$ Crisis $\times$ Risky firm is never significant. ${ }^{14}$

Do the benefits of borrowing diversification depend on firm riskiness? To tackle this issue, we run separately equation 2 on two sub-samples (risky versus risk-free firms) using the same measures of credit risk (see Table 5). We find that risk-free firms always benefit from the countercyclical effect of relationship lending regardless of their diversification profile. Conversely, risky single-bank firms are "held-up" by their opportunistic lender. In line with the theoretical predictions of Rajan (1992)'s, this important insight validates $\mathrm{H} 1 \mathrm{~b}$ and shows that a firm's bargaining power depends on its riskiness. More generally, our findings extend the results of Santos and Winton (2008)'s on large firms given that during crises relationship lenders do not lower their funding costs for SMEs with limited funding options (i.e. risky single-bank firms).

Turning to bank heterogeneity, we then analyse whether bank capitalization affects the insurance mechanism. In this regard, banks with a capital ratio above the third quartile of

13 Musso 1 and Musso 2 refer to Score A and Score B in Musso and Schiavo (2008), respectively.

14 This result, which is consistent with Sette and Gobbi (2015), provides evidence that relationship lending does not have heterogeneous effects on SMEs funding costs according to firm riskiness. 
the sample distribution are considered as well-capitalized. Column (1) in Table 6 presents our results. As assumed in H3, well-capitalized banks are associated with higher relationship lending benefits given their higher ability to finance monitoring costs. Although there are no loan pricing differences between growth and crisis as Duration increases for the two sub-samples (i.e. a non-significant triple interaction), the negative and significant interaction Duration $\times$ Bank variable indicates that well-capitalized banks charge lower rates during good times but also during bad times.

To examine whether banks'capacity to deliver relationship lending depends on their willingness to focus their lending technologies on soft information, we analyse non-tradingoriented business models (i.e. banks with no trading securities) and small banks (i.e. banks whose total assets are below the first quartile of the distribution), given that larger and more organisationally complex banks tend to be more transaction-driven. Columns (2) and (3) of Table 6 show these effects. As regards bank size, the interpretation is the same as for column (1): relationship lending benefits are higher for small banks. Indeed, these banks are more likely to develop closer relationships with their clients. ${ }^{15}$ Finally, in column (3), the positive and significant interaction Duration $\times$ Bank variable indicates that tradingoriented banks not only charge higher rates during good times but also always charge higher rates as the relationship duration increases regardless of the cycle.

Finally, one may be concerned about the fact that the edging effect of relationship lending is not clearly attributable to borrower characteristics or bank characteristics, which, through bank specialization on certain types of borrowers, become correlated with borrower characteristics. Using equation 2 on two sub-samples according to bank capital, bank size and trading, we explore whether relationship lenders behave differently when

15 Moreover, as the skin in the game hypothesis suggests, small banks that have a lower number of clients have an interest in offering continuation lending in order to avoid weakening their capital base. 
they lend to weaker borrowers (i.e. speculative grade firms). To this end, we add the triple interaction Duration $\times$ crisis $\times$ Speculative to control for firm riskiness. Table 7 shows the results: the triple interaction is never significant except in column (6), which indicates that trading-oriented banks always charge higher rates as the relationship duration increases regardless of the cycle, but only for weaker borrowers. For the rest, interacting firm riskiness with bank heterogeneity through the cycle does not affect our previous results.

\subsection{Additional results}

\subsubsection{Diversification and bank's bargaining power}

So far, we only have looked at firms' bargaining power to analyse whether risk-free single-bank firms or firms located in competitive credit markets are able to circumvent the "hold-up" problem. However, bank heterogeneity may also affect this opportunism. Using equation 2 on two sub-samples according to bank capital, bank size and trading, we assess relationship lenders' incentive to support their borrowers during crises. Results are shown in Table 8. Overall, as Duration increases, multiple-bank firms are always charged lower rates in bad times compared to good times. Interestingly, the triple interaction turns out to be positive and significant for large, trading-oriented and well-capitalized banks. The latter are more likely to have a higher bargaining power during crises. As a result, firms benefit the most from diversification in the presence of resilient transaction-driven banks.

\subsubsection{Loan maturity and relationship lending}

Loans are heterogeneous by nature (maturity, outstanding amount, adjustable rate). We therefore investigate whether relationship lending benefits depend on loan maturity. As long-term loans (with a maturity of over one year) imply more monitored and informationintensive processes, relationship lenders are more likely to make use of their information monopoly to smooth interest rates over the cycle. Estimates of column (7) in Table 8 show 
that the countercyclical effect of relationship lending only holds for long-term credit. Accordingly, short-term loans do not benefit from the insurance mechanism outlined above. This intuitive result complements relationship lending analysis that does not focus on loan maturity.

\section{Robustness checks}

\subsection{Endogeneity}

In order to account for the potential reverse causality coming from the Outstanding amount regressor, we re-estimate equation 2 using an instrumental variable strategy. We argue that current accounts receivable capture positive demand shocks that are correlated with the current demand for credit at firm level. Given the non-linearities, we also add a quadratic form in the specification. However, we presume that these variables are not correlated with the level of interest rates (i.e. with the error term). To ensure that our instruments are valid, we run a battery of statistical tests ${ }^{16}$ The results of the instrumental variables estimations are shown in Table 9; as expected, the quadratic form of accounts receivable is positive and significant in the first stage, while the coefficient of the outstanding amount of credit is still negative but no longer significant, which leaves our main result unchanged.

In addition, one may be concerned about the omitted interactions which might create spurious correlations in our estimations (Balli and Sørensen, 2013). Indeed, estimating

\footnotetext{
16 In this regard, the Hansen J-statistic implies that we cannot reject the null hypothesis that all instruments are exogenous, while the Kleibergen-Paap statistic indicates that our instruments are relevant. Besides, we can also reject the null hypothesis of weak instruments when we do not accept an actual test size above $10 \%$ (results available upon request).
} 
a list of models including separately all kinds of interactions does not necessarily show that all these interactions are relevant. Let us consider the case where only one interaction with Crisis is relevant, e.g Firms'size $\times$ Crisis. As long as another variable is correlated with Firm size, e.g. Duration, and the relevant interaction is excluded from the model, this other variable interaction with Crisis will unduly appear to be significant in such regressions. Hence, the same argument applies for the three variables that constitute our triple interaction.

To tackle this issue, we first re-estimate equation 2 including interactions between Duration and firm- and bank-specific variables, as well as interactions between Singlebank and the same variables. In doing so, we allow the impact of Duration and Singlebank to vary across bank and firm characteristics. We then interact these variables with our Crisis dummy in order to control for their non-linear effects over the cycle. Overall, the coefficients related to our main interactions do not change, which shows that potential omitted interactions do not affect our results 17

\subsection{Alternative measure of relationship lending: bank-firm proximity}

As there is no clear consensus on how to identify relationship lending, we have also tested the robustness of the results by considering the informational distance between a lender and a borrower. The physical distance between a bank and a firm affects the banks' ability to gather soft information (Agarwal and Hauswald, 2010). We therefore construct a measure of bank-firm proximity using the CEFIT database to classify banks as local according to the relevance of a given local credit market for the bank and according to the relevance of the bank for that market ${ }^{18}$ Using this definition, local banks represent $67 \%$

17 Results are not reported but available upon request.

18 Using Williams (1991)' specialisation index, we derive a relative measure of credit concentration at bank-level. This measure quantifies the gap between the bank's market share at département level and 
of our observations.

Columns (1) and (2) of Table 10 show our results using the Local bank dummy as an alternative measure of relationship lending ${ }^{19}$. Our main findings hold as in the baseline model. Given its informational advantage over the département, a local bank is more able to smooth interest rates over time. Furthermore, diversification still determines relationship lending benefits over the cycle. Accordingly, our baseline result holds for two different measures that proxy for the bank's ability to gather soft information.

\subsection{Alternative measures of diversification of borrowing}

Investigating alternative measures of borrowing diversification, we run estimations of model 2 using a Herfindahl-Hirschman Index based on credit distribution at département level and we compute a non-bank finance indicator that is likely to affect the firm's bargaining power as in Santos and Winton (2008). The latter is the sum of trade credit and bonds over the firm's total assets and averages $20 \%$. Contrary to our two previous measures, this indicator cannot be associated with relationship lending. Results are presented in columns (3) and (4) of Table 10. They corroborate our main findings.

\subsection{Interest rates including fees and independent SMEs}

The differential effect of relationship lending on single- and multiple-bank firms could be offset by commission fees. As a result, our interest rate measure does not necessarily capture all the services provided by banks, especially implicit contract services, which could bias our results. To address this concern, we add commission fees reported in the

the département market share at national level: a bank is considered as local if its market share at département level is higher than the département's market at national level.

19 The sample size declines sharply given that CEFIT does not include all bank in M-contran. 
M-Contran survey. Column (5) and (6) of Table 10 display the results and show that our estimations are robust to these concerns.

Finally, in order to account for the influence of group affiliation and the possibility of one firm obtaining funding at lower costs with better covenants, we add a dummy variable that takes the value of 1 when the SME is financially independent and zero otherwise. The latter turns out be not significant and does not change our findings 20

\subsection{A Three-period design}

In this section, we explore more detailed cycle decompositions. Based on the quarterly GDP growth rate, we split our benchmark crisis period Q1 2009Q1-Q4 2015 to account for heterogeneities during bad times. Indeed, one may argue that it is unlikely that a downturn would last for six years. However, several indicators suggest that in 2015 France had not recovered from the Great Recession: aggregate investment had not climbed back to its 2008 level and GDP growth was not solid, but rather erratic (see figure 3). Consequently, we split the downturn into two sub-periods: Q1 2009-Q4 2012 and Q1 2013- Q4 2015, the threshold corresponding to the last two consecutive quarters of negative GDP growth. Table 11 estimates equation 2 using this new decomposition. First, relationship banks charge higher rates in good times and lower rates both in period $=1$ and period $=2$. Hence, we show that our two-period decomposition is consistent as there is no difference between these two crisis periods. Interestingly, the triple interaction turns out to be positive and significant for both crisis periods, suggesting that the downturn has continued after 2013. In addition, in column (3), given the developments in our dependent variable in figure 2 , we drop the year 2008 to avoid capturing first warning signs of the crisis during the period 2006-2008. Overall, these different business cycle decompositions do not alter our main

\footnotetext{
20 Independent SMEs represent $48 \%$ of our sample. Results are unreported but available upon request.
} 
results.

\section{Conclusion and policy implications}

We investigate to what extent relationship lending affects interest rate setting over the cycle according to the firm's ability to diversify its borrowing. Using the length of the relationship, we find that relationship lenders charge higher rates in good times and lower rates in bad times. However, we stress that this effect is undermined for firms whose ability to diversify is lower, i.e. single-bank firms, firms involved in concentrated local credit markets and highly bank-dependent firms. In this regard, only risky firms benefit from diversification insofar as relationship lenders use their informational advantage to raise funding costs for SMEs with lower bargaining power during crises.

We also find that main banks charge lower rates during bad times compared to good times due to "skin in the game" effects. Yet, this benefit vanishes during crises as the duration of the relationship increases, which shows that dealing with a main bank could also undermine firms' bargaining power. Furthermore, we show that our main results only apply to information-intensive loans (i.e. long-term loans), while small, non-trading-oriented and well-capitalized banks drive the benefits of relationship lending during crises. Finally, investigating the determinants of banks' bargaining power, we find that well-capitalized transaction-driven banks adopt an opportunistic loan pricing during crises.

Our paper supports the new banking regulation on capital ratios as well-capitalized banks increase relationship lending benefits over the cycle. Furthermore, our results suggest ways of improving SMEs' investment, such as promoting local bank competition or multiple banking. These are the main strands for the future regulation. 


\section{References}

Adrian, T., and Shin, H. S. (2010). Liquidity and leverage. Journal of Financial Intermediation, 19, 418-437.

Agarwal, S., and Hauswald, R. (2010). Distance and private information in lending. The Review of Financial Studies, 23, 2757-2788.

Balli, H. O., and Sørensen, B. E. (2013). Interaction effects in econometrics. Empirical Economics, 45, 583-603.

Berger, A. N., and Udell, G. F. (1992). Some evidence on the empirical significance of credit rationing. Journal of Political Economy, 100, 1047-1077.

Berger, A. N., and Udell, G. F. (2002). Small business credit availability and relationship lending: The importance of bank organisational structure. The Economic Journal, 112.

Berlin, M., and Mester, L. J. (1999). Deposits and relationship lending. The Review of Financial Studies, 12, 579-607.

Bernanke, B., and Gertler, M. (1989). Agency costs, net worth, and business fluctuations. The American Economic Review, 79, 14-31.

Bolton, P., Freixas, X., Gambacorta, L., and Mistrulli, P. E. (2016). Relationship and transaction lending in a crisis. The Review of Financial Studies, 29, 2643-2676.

Boot, A. W. (2000). Relationship banking: What do we know? Journal of Financial Intermediation, 9, 7-25.

Boot, A. W., and Thakor, A. V. (2000). Can relationship banking survive competition? The Journal of Finance, 55, 679-713. 
Carletti, E., Cerasi, V., and Daltung, S. (2007). Multiple-bank lending: Diversification and free-riding in monitoring. Journal of Financial Intermediation, 16, 425-451.

Degryse, H., and Ongena, S. (2007). The impact of competition on bank orientation. Journal of Financial Intermediation, 16, 399-424.

Detragiache, E., Garella, P., and Guiso, L. (2000). Multiple versus single banking relationships: Theory and evidence. The Journal of Finance, 55, 1133-1161.

Diamond, D. W. (1984). Financial intermediation and delegated monitoring. The Review of Economic Studies, 51, 393-414.

Elsas, R. (2005). Empirical determinants of relationship lending. Journal of Financial Intermediation, 14, 32-57.

Farinha, L. A., and Santos, J. A. (2002). Switching from single to multiple bank lending relationships: Determinants and implications. Journal of Financial Intermediation, 11, $124-151$.

Fungáčová, Z., Shamshur, A., and Weill, L. (2017). Does bank competition reduce cost of credit? Cross-country evidence from Europe. Journal of Banking $\mathcal{F}$ Finance, 83, $104-120$.

Gambacorta, L., and Mistrulli, P. E. (2014). Bank heterogeneity and interest rate setting: what lessons have we learned since Lehman Brothers? Journal of Money, Credit and Banking, 46, 753-778.

Gertler, M., and Gilchrist, S. (1994). Monetary policy, business cycles, and the behavior of small manufacturing firms. The Quarterly Journal of Economics, 109, 309-340. 
Gobbi, G., and Sette, E. (2013). Do firms benefit from concentrating their borrowing? Evidence from the Great Recession. Review of Finance, 18, 527-560.

Harris, M., and Holmstrom, B. (1982). A theory of wage dynamics. The Review of Economic Studies, 49, 315-333.

Hernández-Cánovas, G., and Koëter-Kant, J. (2010). The institutional environment and the number of bank relationships: an empirical analysis of European SMEs. Small Business Economics, 34, 375-390.

Holmstrom, B., and Tirole, J. (1997). Financial intermediation, loanable funds, and the real sector. The Quarterly Journal of Economics, 112, 663-691.

Ioannidou, V., and Ongena, S. (2010). "Time for a change": loan conditions and bank behavior when firms switch banks. The Journal of Finance, 65, 1847-1877.

Iyer, R., Peydró, J.-L., da Rocha-Lopes, S., and Schoar, A. (2014). Interbank liquidity crunch and the firm credit crunch: Evidence from the 2007-2009 crisis. The Review of Financial Studies, 27, 347-372.

Jiménez, G., and Ongena, S. (2012). Credit supply and monetary policy: Identifying the bank balance-sheet channel with loan applications. The American Economic Review, $102,2301-2326$.

Kashyap, A. K., and Stein, J. C. (2000). What do a million observations on banks say about the transmission of monetary policy? The American Economic Review, 90, 407-428.

Khwaja, A. I., and Mian, A. (2008). Tracing the impact of bank liquidity shocks: Evidence from an emerging market. The American Economic Review, 98, 1413-1442. 
Liberti, J. M., and Mian, A. R. (2009). Estimating the effect of hierarchies on information use. The Review of Financial Studies, 22, 4057-4090.

Musso, P., and Schiavo, S. (2008). The impact of financial constraints on firm survival and growth. Journal of Evolutionary Economics, 18, 135-149.

Ongena, S., and Smith, D. C. (2000). Bank Relationships: A Review. Cambridge University Press.

Ongena, S., and Smith, D. C. (2001). The duration of bank relationships. Journal of Financial Economics, 61, 449-475.

Peek, J., and Rosengren, E. S. (2000). Collateral damage: Effects of the Japanese bank crisis on real activity in the United States. The American Economic Review, 90, 30-45.

Petersen, M. A., and Rajan, R. G. (1994). The benefits of lending relationships: Evidence from small business data. The Journal of Finance, 49, 3-37.

Petersen, M. A., and Rajan, R. G. (1995). The effect of credit market competition on lending relationships. The Quarterly Journal of Economics, 110, 407-443.

Presbitero, A. F., and Zazzaro, A. (2011). Competition and relationship lending: Friends or foes? Journal of Financial Intermediation, 20, 387-413.

Puri, M., Rocholl, J., and Steffen, S. (2011). Global retail lending in the aftermath of the US financial crisis: Distinguishing between supply and demand effects. Journal of Financial Economics, 100, 556-578.

Rajan, R. G. (1992). Insiders and outsiders: The choice between informed and arm'slength debt. The Journal of Finance, 47, 1367-1400. 
Santos, J. A., and Winton, A. (2008). Bank loans, bonds, and information monopolies across the business cycle. The Journal of Finance, 63, 1315-1359.

Schularick, M., and Taylor, A. M. (2012). Credit booms gone bust: monetary policy, leverage cycles, and financial crises, 1870-2008. The American Economic Review, 102, 1029-1061.

Sette, E., and Gobbi, G. (2015). Relationship lending during a financial crisis. Journal of the European Economic Association, 13, 453-481.

Sharpe, S. A. (1990). Asymmetric information, bank lending, and implicit contracts: A stylized model of customer relationships. The Journal of Finance, 45, 1069-1087.

Williams, R. A. (1991). Measuring submarket specialisation by firms. Economics Letters, 36, 291-294.

Williamson, O. E. (1967). Hierarchical control and optimum firm size. Journal of Political Economy, 75, 123-138. 
Figure 1: Cycle measure 1: the two-period decomposition

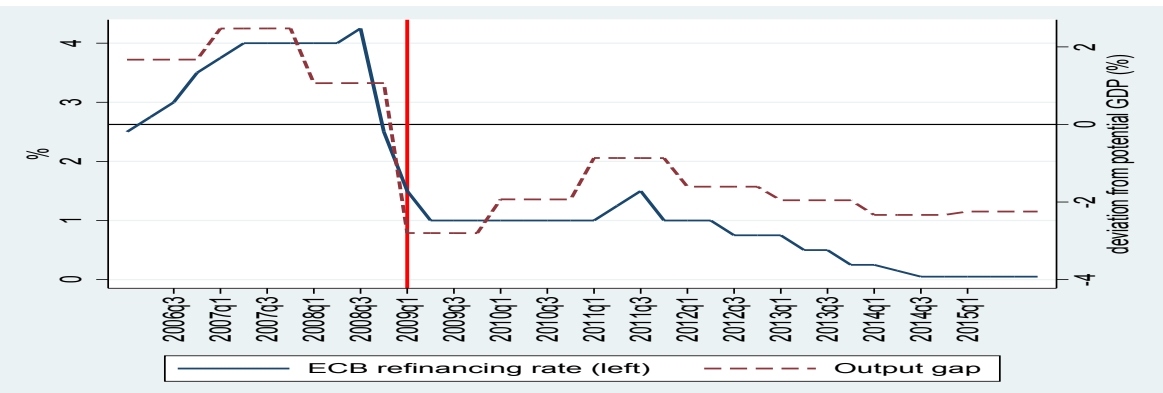

Sources: Banque de France (ECB refinancing rate) and OECD (Output gap).

Figure 2: Average interest rate by loan maturity

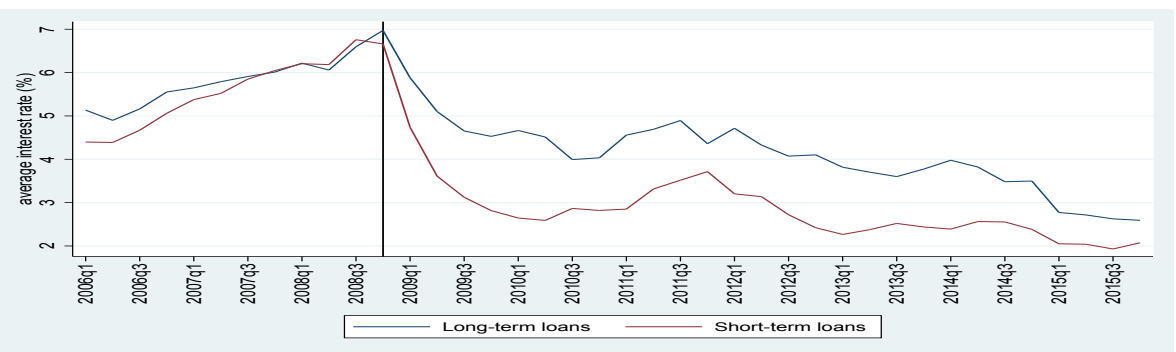

Source : authors' database and authors' calculations.

Figure 3: Three-period design

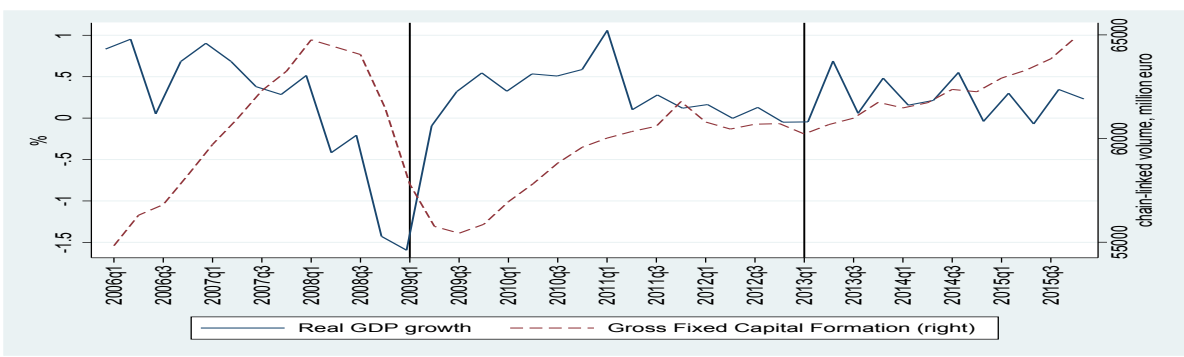

Source : Institut National de la Statistique et des Etudes Economiques (INSEE). 
Table 1: Quantitative summary statistics

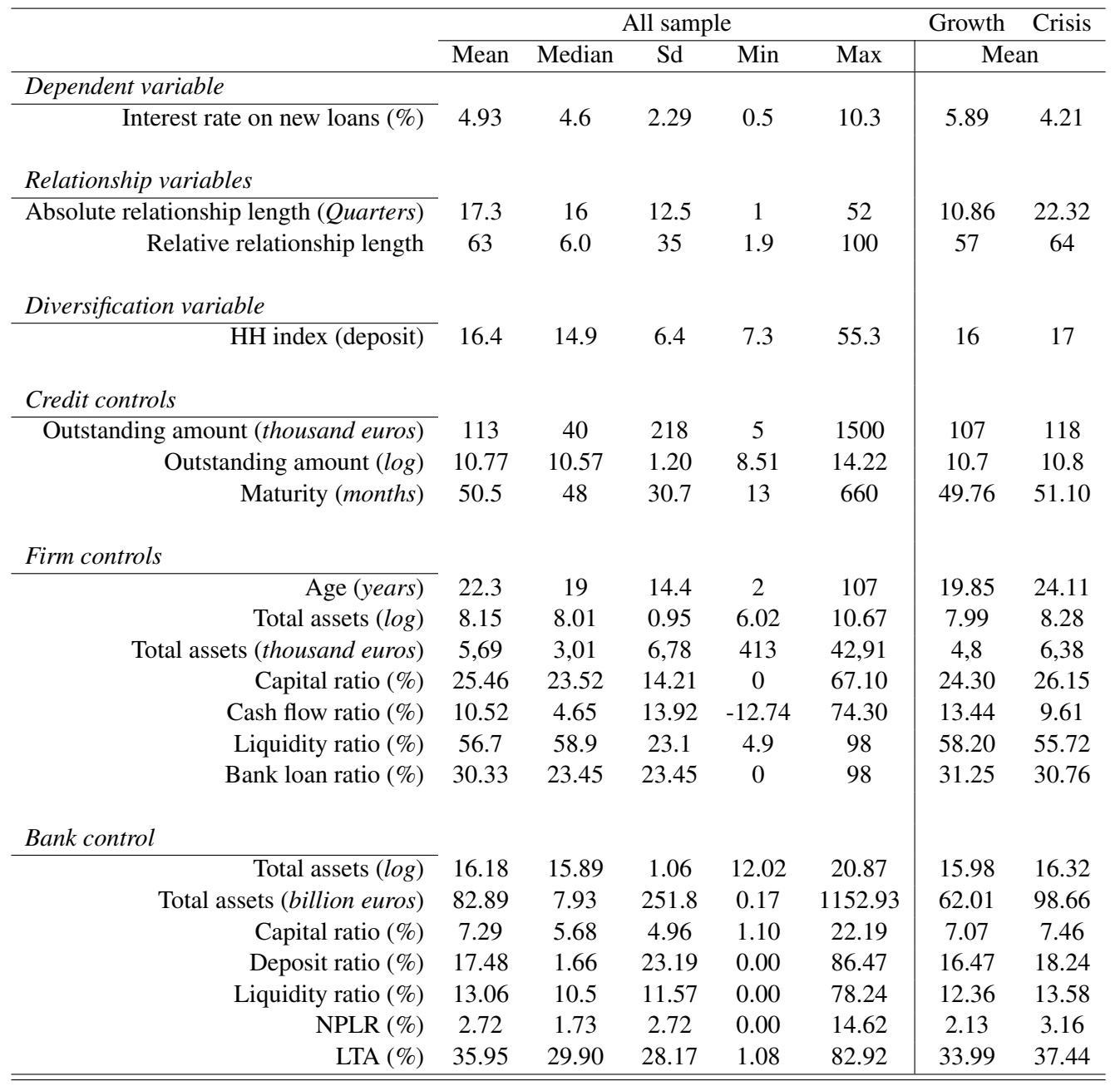

Note : the last two columns show the mean of endogeneous and exogeneous variables over the main cycle decomposition : Q1 2006-Q4 2008 (Growth) and Q1 2009-Q4 2015 (Crisis). 
Table 2: Relationship lending and single banking over the cycle

\begin{tabular}{|c|c|c|c|}
\hline & \multicolumn{3}{|c|}{ Dependent variable $=$ Cost of credit } \\
\hline & (1) & (2) & (3) \\
\hline \multicolumn{4}{|l|}{ Relationship lending } \\
\hline Duration $_{t}$ & $\begin{array}{c}0.002 * * * \\
(0.000)\end{array}$ & $\begin{array}{c}0.002 * * * \\
(0.000)\end{array}$ & $\begin{array}{c}0.002 * * * \\
(0.000)\end{array}$ \\
\hline Single-bank $t_{t}$ & $\begin{array}{c}0.019 \\
(0.051)\end{array}$ & $\begin{array}{l}-0.019 \\
(0.082)\end{array}$ & $\begin{array}{c}-0.019 \\
(0.081)\end{array}$ \\
\hline Crisis $_{t}$ & $\begin{array}{c}-1.302 * * * \\
(0.088)\end{array}$ & $\begin{array}{c}-1.300 * * * \\
(0.088)\end{array}$ & $\begin{array}{c}-1.187 * * * \\
(0.114)\end{array}$ \\
\hline Duration $_{t} \times$ Crisis $_{t}$ & $\begin{array}{c}-0.003 * * * \\
(0.000)\end{array}$ & $\begin{array}{c}-0.003 * * * \\
(0.000)\end{array}$ & $\begin{array}{c}-0.003 * * * \\
(0.000)\end{array}$ \\
\hline Duration $_{t} \times$ Single-bank $_{t}$ & & $\begin{array}{c}0.001 \\
(0.001)\end{array}$ & $\begin{array}{c}0.001 \\
(0.001)\end{array}$ \\
\hline Single-bank $t \times$ Crisis $_{t}$ & $\begin{array}{l}-0.059 \\
(0.055)\end{array}$ & $\begin{array}{c}-0.185^{* *} \\
(0.178)\end{array}$ & $\begin{array}{c}-0.185 * * \\
(0.179)\end{array}$ \\
\hline Duration $_{t} \times$ Crisis $_{t} \times$ Single-bank $_{t}$ & & $\begin{array}{c}0.005^{* *} \\
(0.002)\end{array}$ & $\begin{array}{c}0.005^{* *} \\
(0.002)\end{array}$ \\
\hline \multicolumn{4}{|l|}{ Market controls } \\
\hline Herfindahl $_{t}$ & $\begin{array}{c}0.002 \\
(0.003)\end{array}$ & $\begin{array}{c}0.002 \\
(0.003)\end{array}$ & $\begin{array}{l}-0.007 \\
(0.009)\end{array}$ \\
\hline Herfindahl $_{t}^{2}$ & & & $\begin{array}{c}0.021 \\
(0.019)\end{array}$ \\
\hline \multicolumn{4}{|l|}{ Loan controls } \\
\hline Maturity $_{t}$ & $\begin{array}{c}0.001 * * * \\
(0.000)\end{array}$ & $\begin{array}{c}0.001 * * * \\
(0.000)\end{array}$ & $\begin{array}{c}0.001^{* * * *} * \\
(0.000)\end{array}$ \\
\hline Outstanding amount $t(\log )$ & $\begin{array}{c}-0.123 * * * \\
(0.001)\end{array}$ & $\begin{array}{c}-0.123 * * * \\
(0.001)\end{array}$ & $\begin{array}{c}-0.123 * * * \\
(0.001)\end{array}$ \\
\hline Adjustable rate ${ }_{t}$ & $\begin{array}{c}-0.095^{* * *} \\
(0.026)\end{array}$ & $\begin{array}{c}-0.095^{* * *} \\
(0.026)\end{array}$ & $\begin{array}{c}-0.091 * * * \\
(0.026)\end{array}$ \\
\hline \multicolumn{4}{|l|}{ Firm controls } \\
\hline $\mathrm{Age}_{t}$ & $\begin{array}{l}-0.005 \\
(0.005)\end{array}$ & $\begin{array}{l}-0.005 \\
(0.005)\end{array}$ & $\begin{array}{l}-0.005 \\
(0.005)\end{array}$ \\
\hline Total assets $_{t-1}(\log )$ & $\begin{array}{c}-0.051 * \\
(0.029)\end{array}$ & $\begin{array}{c}-0.051^{*} \\
(0.029)\end{array}$ & $\begin{array}{c}-0.051^{*} \\
(0.029)\end{array}$ \\
\hline Bank loan ratio $t_{t-1}$ & $\begin{array}{c}0.007 \\
(0.044)\end{array}$ & $\begin{array}{c}0.007 \\
(0.044)\end{array}$ & $\begin{array}{c}0.007 \\
(0.044)\end{array}$ \\
\hline Capital ratio $t_{t-1}$ & $\begin{array}{c}-0.005^{* * *} \\
(0.001)\end{array}$ & $\begin{array}{c}-0.005^{* * *} \\
(0.001)\end{array}$ & $\begin{array}{c}-0.005 * * * \\
(0.001)\end{array}$ \\
\hline Liquidity ratio r-1 $_{t}$ & $\begin{array}{c}-0.002 * * \\
(0.001)\end{array}$ & $\begin{array}{c}-0.002 * * \\
(0.001)\end{array}$ & $\begin{array}{c}-0.002 * * \\
(0.001)\end{array}$ \\
\hline Cash flow ratio $t-1$ & $\begin{array}{l}-0.001 \\
(0.000)\end{array}$ & $\begin{array}{l}-0.001 \\
(0.000)\end{array}$ & $\begin{array}{l}-0.001 \\
(0.000)\end{array}$ \\
\hline
\end{tabular}

Notes : Continues on the next page. 
Table 2: Relationship lending and single banking over the cycle (continued)

\begin{tabular}{|c|c|c|c|}
\hline & \multicolumn{3}{|c|}{ Dependent variable $=$ Cost of credit } \\
\hline & (1) & $(2)$ & (3) \\
\hline \multicolumn{4}{|l|}{ Bank controls } \\
\hline Total assets $_{t-1}(\log )$ & $\begin{array}{c}-0.301 * * * \\
(0.041)\end{array}$ & $\begin{array}{c}-0.302 * * * \\
(0.041)\end{array}$ & $\begin{array}{c}-0.364 * * * \\
(0.06)\end{array}$ \\
\hline Deposit ratio $t-1$ & $\begin{array}{c}-0.016 * * * \\
(0.002)\end{array}$ & $\begin{array}{c}-0.016 * * * \\
(0.002)\end{array}$ & $\begin{array}{c}-0.016 * * * \\
(0.002)\end{array}$ \\
\hline Capital ratio $_{t-1}$ & $\begin{array}{c}-0.007 * \\
(0.004)\end{array}$ & $\begin{array}{c}-0.007 * \\
(0.004)\end{array}$ & $\begin{array}{c}-0.055 * * * \\
(0.015)\end{array}$ \\
\hline Capital ratio ${ }_{t-1}^{2}$ & & & $\begin{array}{c}0.002 * * * \\
(0.001)\end{array}$ \\
\hline Liquidity ratio ${ }_{t-1}$ & $\begin{array}{c}0.016 * * * \\
(0.001)\end{array}$ & $\begin{array}{c}0.016 * * * \\
(0.001)\end{array}$ & $\begin{array}{c}0.015^{* * *} * \\
(0.002)\end{array}$ \\
\hline $\mathrm{NPLR}_{t-1}$ & $\begin{array}{c}0.050 * * * \\
(0.006)\end{array}$ & $\begin{array}{c}0.051 * * * \\
(0.009)\end{array}$ & $\begin{array}{c}0.049 * * * \\
(0.008)\end{array}$ \\
\hline $\mathrm{LTA}_{t-1}$ & $\begin{array}{c}0.001 \\
(0.001)\end{array}$ & $\begin{array}{c}0.001 \\
(0.002)\end{array}$ & $\begin{array}{c}0.002 \\
(0.002)\end{array}$ \\
\hline Firm, bank and time fixed effects & Yes & Yes & Yes \\
\hline Obs. & 49,798 & 49,798 & 49,798 \\
\hline Firms & 11,278 & 11,278 & 11,278 \\
\hline Overall $R^{2}$ & 0.717 & 0.717 & 0.717 \\
\hline Within $R^{2}$ & 0.719 & 0.719 & 0.719 \\
\hline Between $R^{2}$ & 0.757 & 0.756 & 0.757 \\
\hline
\end{tabular}

Notes : This table shows the regression results of a within estimation of equation 1 in column (1) and equation 2 in columns (2) and (3). Duration is the normalised relationship length and the Single-bank dummy equals 1 when the firm is a single-bank firm. Crisis is a dummy that takes the value 0 from Q1 2006 to Q4 2008 and 1 from Q1 2009 to Q4 2015. We also add in column (1) an interaction term between single-bank firms and the crisis dummy. Columns $(1)$ and $(2,3)$ differ according to whether or not a triple interaction term is included. Note also that the triple interaction coefficient estimates the difference between the average effect of duration over the cycle of single-bank and multiple-bank firms. Column (3) analyses two non-linearities: the Herfindahl index and the bank capital ratio. All regressions include firm, bank, market and loan controls as well as firm, bank and time fixed effects (coefficients are not reported but available upon request). The Hausman test rejects the null hypothesis of random effect estimator consistency. Standard errors (in brackets) are double clustered at firm-level and bank-level and are heteroscedasticity consistent. $*, * *$ and $* * *$ indicate significance levels at $10 \%, 5 \%$ and $1 \%$ respectively. 
Table 3: Role of the main bank

\begin{tabular}{rcc}
\hline & \multicolumn{2}{c}{ Dependent variable $=$ Cost of credit } \\
\cline { 2 - 3 } & $(1)$ & $(2)$ \\
\hline Main bank $_{t}$ & -0.021 & -0.057 \\
& $(0.019)$ & $(0.057)$ \\
Duration $_{t} \times$ Main $_{t} \times$ Crisis $_{t}$ & $-0.113^{* * *}$ & $-0.157^{* * *}$ \\
& $(0.025)$ & $(0.052)$ \\
& & 0.001 \\
& & $(0.001)$ \\
Duration $_{t} \times$ Crisis $_{t} \times$ Main bank $_{t}$ & & $0.001^{*}$ \\
& & $(0.001)$ \\
\hline All time-varying controls & Yes & Yes \\
Obank and time fixed effects & Yes & Yes \\
Obs. & 47,082 & 47,082 \\
Firms & 10,460 & 10,460 \\
Overall $R^{2}$ & 0.721 & 0.722 \\
Within $R^{2}$ & 0.724 & 0.722 \\
Between $R^{2}$ & 0.759 & 0.759 \\
\hline \hline
\end{tabular}

Notes : This table shows the regression results of a within estimation of equation 11 in column (1) and equation 2 in column (2). Main bank equals 1 if the firm borrows from its main bank and 0 otherwise. Duration is the normalised relationship length and Crisis is a dummy that takes the value 0 from Q1 2006 to Q4 2008 and 1 from Q1 2009 to Q4 2015. Column (1) (resp. (2)) does not include (resp. includes) a triple interaction term. All regressions include firm, bank, market and loan controls as well as firm, bank and time fixed effects (coefficients are not reported but available upon request). The Hausman test rejects the null hypothesis of random effect estimator consistency. Standard errors (in brackets) are double clustered at firm-level and bank-level and are heteroscedasticity consistent. *, ** and $* * *$ indicate significance levels at $10 \%, 5 \%$ and $1 \%$ respectively. 
Table 4: Bank competition effects on relationship lending over the cycle

\begin{tabular}{rccc}
\hline & \multicolumn{3}{c}{ Dependent variable $=$ Cost of credit } \\
\cline { 2 - 4 } & All sample & Small Banks & Large banks \\
& $(1)$ & $(2)$ & $(3)$ \\
\hline Duration $_{t}$ & $0.001^{* * *}$ & 0.001 & $0.002^{* * *}$ \\
& $(0.000)$ & $(0.001)$ & $(0.000)$ \\
Duration $_{t} \times$ Crisis $_{t}$ & $-0.002^{* * *}$ & $-0.002^{* *}$ & $-0.003^{* * *}$ \\
& $(0.000)$ & $(0.001)$ & $(0.000)$ \\
Duration $_{t} \times$ Competition $_{t}$ & $0.001 *$ & 0.002 & $0.001 * *$ \\
& $(0.000)$ & $(0.001)$ & $(0.000)$ \\
Duration $_{t} \times$ Crisis $_{t} \times$ Competition $_{t}$ & $-0.002^{* *}$ & $-0.004 * *$ & -0.001 \\
& $(0.001)$ & $(0.002)$ & $(0.001)$ \\
\hline Fill time-varying controls & Yes & Yes & Yes \\
Fank and time fixed-effects & Yes & Yes & Yes \\
Obs. $_{\text {Fim }}$ & 49,798 & 8072 & 32882 \\
Firms & 11,278 & 1885 & 8191 \\
${\text { Overall } R^{2}}$ & 0.720 & 0.490 & 0.791 \\
Within $R^{2}$ & 0.722 & 0.593 & 0.766 \\
${\text { Between } R^{2}}$ & 0.760 & 0.485 & 0.814 \\
\hline \hline
\end{tabular}

Notes: This table shows the regression results of a within estimation of equation 2. Duration is the normalised relationship length, Crisis is a dummy that takes the value 0 from Q1 2006 to Q4 2008 and 1 from Q1 2009 to Q4 2015. Competition is a dummy variable which equals 1 for competitive local credit markets (i.e. local credit markets that belong to the first quartile of the distribution of the Herfindahl Hirschman Index based on deposits). While column (1) focuses on the whole sample, column (2) restricts the sample to Small banks (i.e. banks whose total assets are below the first quartile of the distribution of the entire sample) and column (3) restricts the sample to Large banks(i.e. banks whose total assets are not below the first quartile of the distribution of the entire sample. All regressions include firm, bank, market and loan controls as well as firm, bank and time fixed effects (coefficients are not reported but available upon request). The Hausman test rejects the null hypothesis of random effect estimator consistency. Standard errors (in brackets) are double clustered at firm-level and bank-level and are heteroscedasticity consistent. *, ** and $* * *$ indicate significance levels at $10 \%, 5 \%$ and $1 \%$ respectively. 


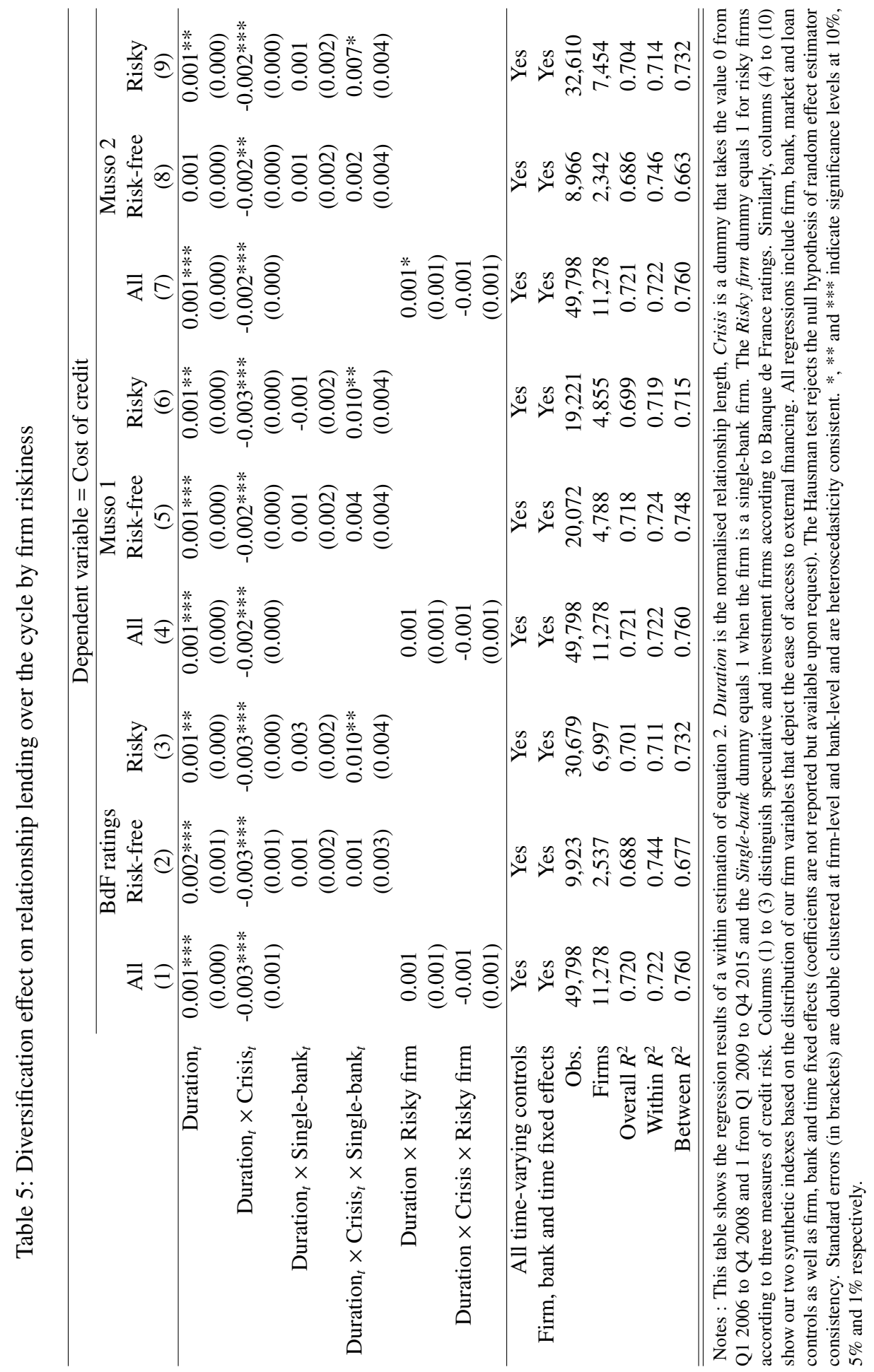


Table 6: Bank characteristics and relationship lending over the cycle

\begin{tabular}{rccc}
\hline & \multicolumn{3}{c}{ Dependent variable $=$ Cost of credit } \\
\cline { 2 - 4 } Bank characteristic & Well-capitalized & Small & Trading-bank \\
& $(1)$ & $(2)$ & $(3)$ \\
\hline Duration & $0.002^{* * *}$ & $0.002^{* * *}$ & 0.001 \\
& $(0.000)$ & $(0.000)$ & $(0.000)$ \\
Duration $\times$ Crisis & $-0.002^{* * *}$ & $-0.002^{* * *}$ & $-0.002^{* * *}$ \\
& $(0.000)$ & $(0.000)$ & $(0.000)$ \\
Duration $\times$ Bank variable & $-0.002^{* * *}$ & $-0.002 * *$ & $0.003 * * *$ \\
& $(0.001)$ & $(0.001)$ & $(0.001)$ \\
Duration $\times$ Crisis $\times$ Bank variable & -0.001 & -0.001 & -0.001 \\
& $(0.001)$ & $(0.001)$ & $(0.001)$ \\
\hline All time-varying controls & Yes & Yes & Yes \\
Firm, bank and time fixed effects & Yes & Yes & Yes \\
Obs. & 49,798 & 49,798 & 49,798 \\
Firms & 11,278 & 11,278 & 11,278 \\
Overall $R^{2}$ & 0.721 & 0.724 & 0.723 \\
Within $R^{2}$ & 0.722 & 0.724 & 0.725 \\
Between $R^{2}$ & 0.760 & 0.762 & 0.761 \\
\hline \hline
\end{tabular}

Notes : This table shows the regression results of a within estimation of equation 2. Duration is the normalised relationship length, Crisis is a dummy that takes the value 0 from Q1 2006 to Q4 2008 and 1 from Q1 2009 to Q4 2015. The Bank variable dummy equals 1 for well-capitalized banks in column (1) (i.e. banks with a capital ratio above the third quartile of the distribution of the entire sample), small banks in column (2) (i.e. banks whose total assets are below the first quartile of the distribution of the entire sample) or trading-banks in column (2) (i.e. banks that hold trading securities), and 0 otherwise. All regressions include firm, bank, market and loan controls as well as firm, bank and time fixed effects (coefficients are not reported but available upon request). The Hausman test rejects the null hypothesis of random effect estimator consistency. Standard errors (in brackets) are double clustered at firm-level and bank-level and are heteroscedasticity consistent. *, ** and *** indicate significance levels at $10 \%, 5 \%$ and $1 \%$ respectively. 


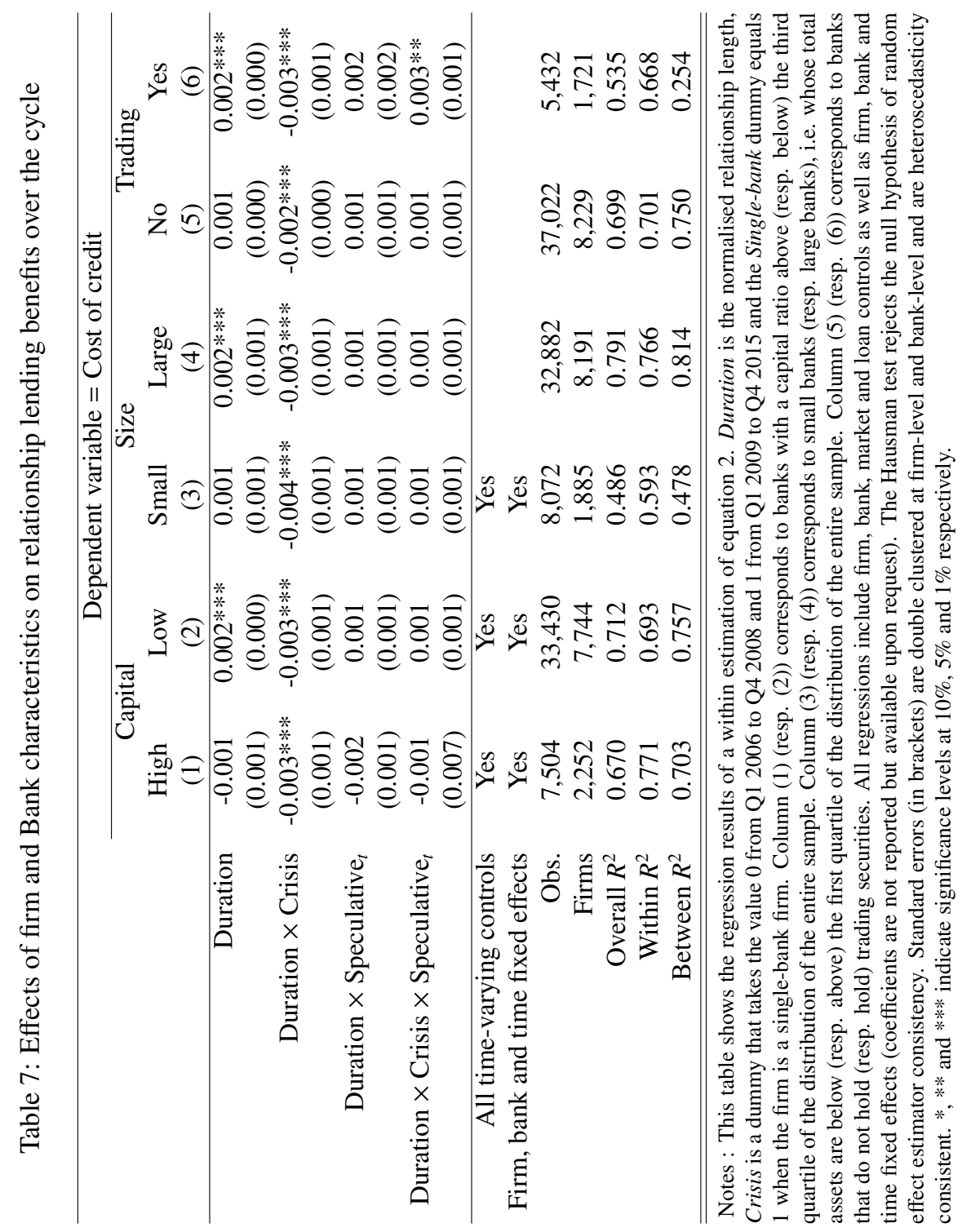




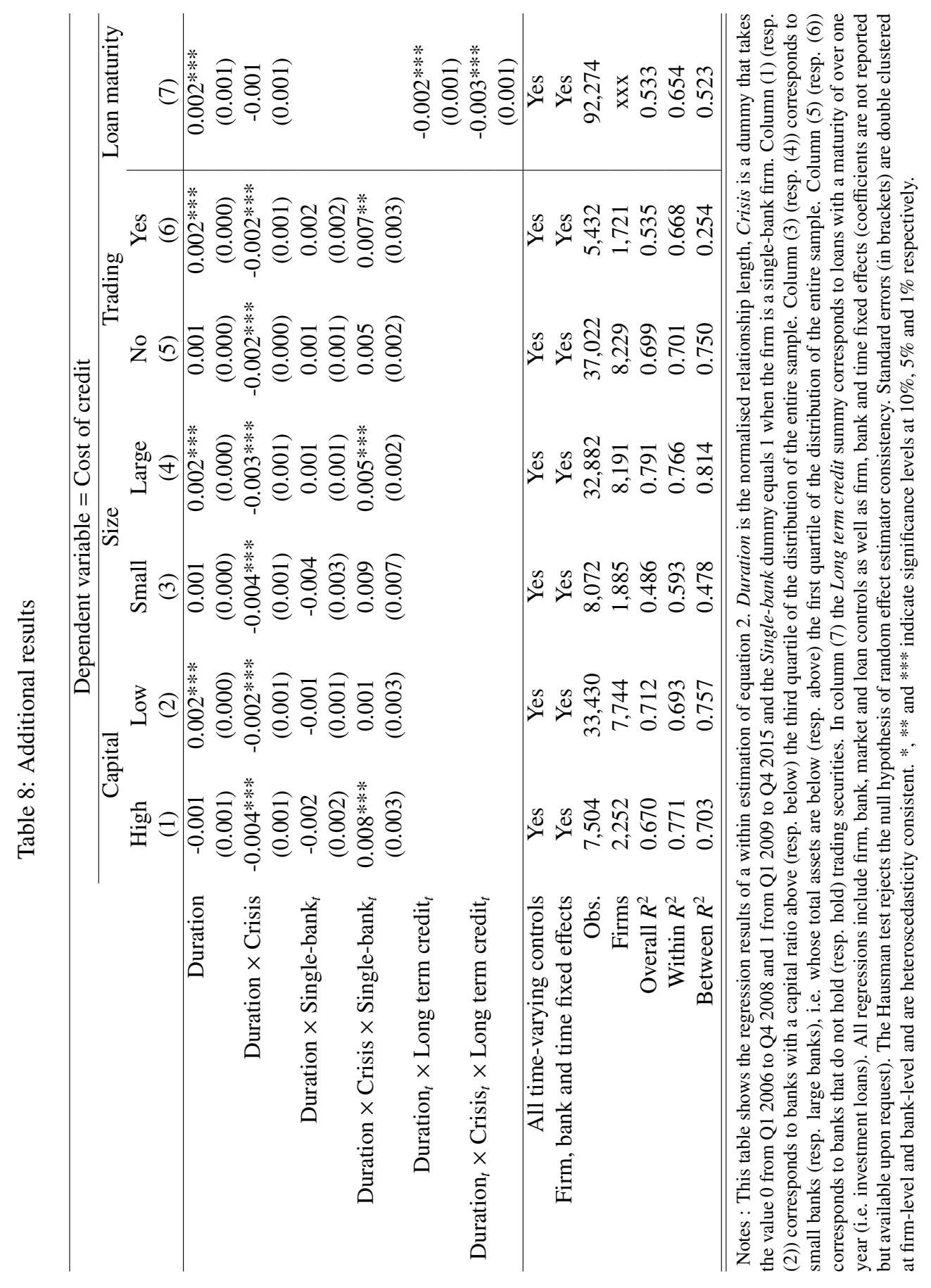


Table 9: IV estimation (robustness check)

\begin{tabular}{|c|c|c|}
\hline Dependent variable & $\begin{array}{c}\text { Outstanding amount } \\
\text { (1) }\end{array}$ & $\begin{array}{l}\text { Cost of credit } \\
\text { (2) }\end{array}$ \\
\hline Outstanding amount $t_{t}$ & & $\begin{array}{l}-0.096 \\
(0.245)\end{array}$ \\
\hline Duration $_{t}$ & $\begin{array}{r}-0.001 * \\
(0.019)\end{array}$ & $\begin{array}{c}0.001 * * * \\
(0.001)\end{array}$ \\
\hline Duration $_{t} \times$ Crisis $_{t}$ & $\begin{array}{l}-0.001 \\
(0.025)\end{array}$ & $\begin{array}{c}-0.003 * * * \\
(0.001)\end{array}$ \\
\hline Duration $_{t} \times$ Single-banked $_{t}$ & $\begin{array}{c}0.001 \\
(0.001)\end{array}$ & $\begin{array}{c}0.001 \\
(0.001)\end{array}$ \\
\hline Duration $_{t} \times$ Crisis $_{t} \times$ Single-banked $_{t}$ & $\begin{array}{l}-0.001 \\
(0.002)\end{array}$ & $\begin{array}{c}0.005^{* *} \\
(0.002)\end{array}$ \\
\hline Accounts receivable $_{t}(\log )$ & $\begin{array}{c}-0.059 \\
(0.080)\end{array}$ & \\
\hline Accounts receivable ${ }^{2}(\log )$ & $\begin{array}{c}0.012 * * \\
(0.005)\end{array}$ & \\
\hline All time-varying controls & Yes & Yes \\
\hline Firm, bank and time fixed effects & Yes & Yes \\
\hline F-statistic & $27.40 * * *$ & \\
\hline Hansen J statistic & & 0.031 \\
\hline Obs. & 49,798 & 49,798 \\
\hline Firms & 11,278 & 11,278 \\
\hline
\end{tabular}

Notes : This table shows the IV estimation of a within estimation of equation 2. Column (1) and column (2) correspond to the first and second stage, respectively. Duration is the normalised relationship length, Crisis is a dummy that takes the value 0 from Q1 2006 to Q4 2008 and 1 from Q1 2009 to Q4 2015 and the Single-bank dummy equals 1 when the firm is a single-bank firm. All regressions include firm, bank, market and loan controls as well as firm, bank and time fixed effects (coefficients are not reported but available upon request). The Hansen $\mathbf{J}$ statistics implies that we cannot reject the null hypothesis that all instruments are exogenous, while the Kleibergen-Paap rk Wald $\mathrm{F}$ statistic indicates that our instruments are relevant. Standard errors (in brackets) are double clustered at firm-level and bank-level and are heteroscedasticity consistent. *,** and $* * *$ indicate significance levels at $10 \%, 5 \%$ and $1 \%$ respectively. 


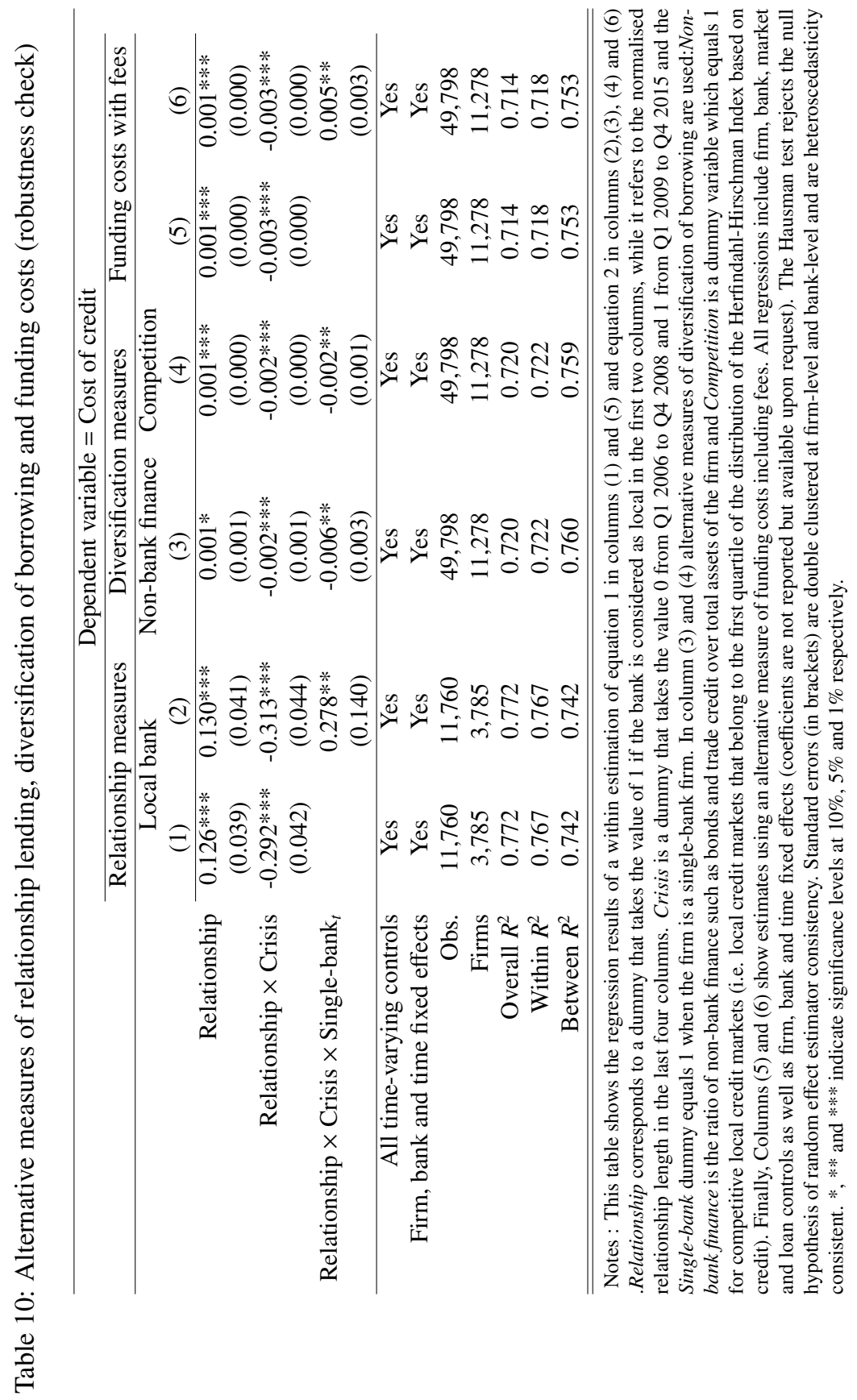


Table 11: Alternative time decompositions (robustness check)

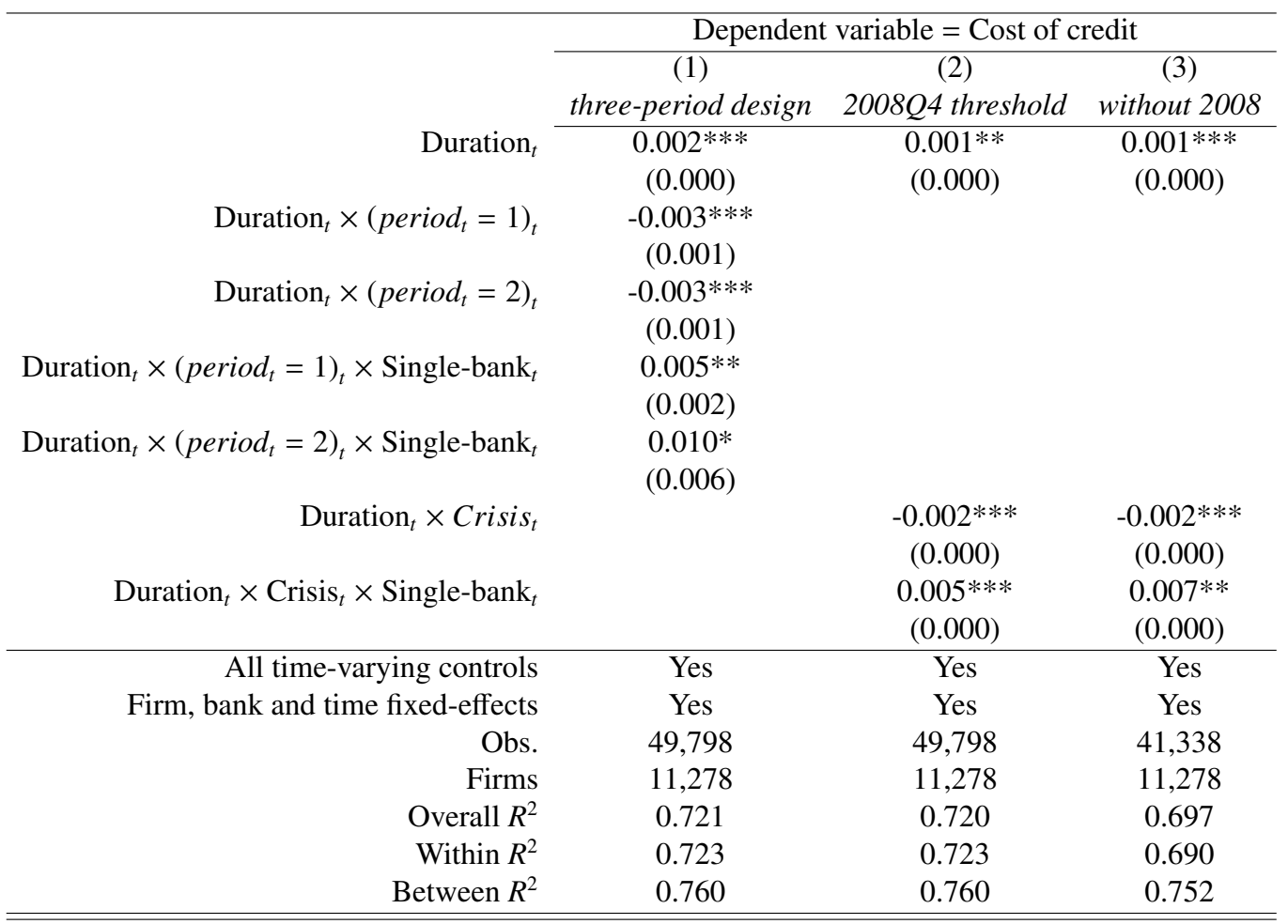

Notes : This table shows the regression results of a within estimation of equation 2 using our three-period design. Duration is the relative relationship length, period is a categorical variable that takes the value of 0 from Q1 2006 to Q4 2008,1 from Q1 2009 to Q4 2012 and 2 from Q1 2013 to Q4 2015 and Crisis is a dummy that takes the value of 1 from Q1 2009 to Q4 2015 in column(2) or from Q4 2008 to Q4 2015 in column (3). Column (1) shows our three-period design described in 6.5, column (2) estimates equation 2 with the crisis starting in Q4 2008 and column (3) estimates equation 2 with a sub-sample excluding 2008. All regressions include firm, bank, market and loan controls as well as firm, bank and time fixed effects (coefficients are not reported but available upon request). The Hausman test rejects the null hypothesis of random effect estimator consistency. Standard errors (in brackets) are double clustered at firm-level and bank-level and are heteroscedasticity consistent. *,** and $* * *$ indicate significance levels at $10 \%, 5 \%$ and $1 \%$ respectively. 